\title{
Os Dois Papas: uma reflexão a respeito do princípio protestante e a substância católica a partir da teologia da cultura
}

\author{
Pablo Fernando Dumer*
}

\begin{abstract}
RESUMO
O artigo analisa a obra cinematográfica Dois Papas a partir da teologia da cultura de Paul Tillich e dos seus conceitos de princípio protestante e substância católica. O filme apresenta ao espectador uma reflexão, desde a diferença entre os dois personagens, de dois destinos e dois modelos eclesiológicos e teológicos distintos. Mais que apenas a condição do catolicismo contemporâneo, o filme traz reflexões da teologia e cristianismo como um todo. Impulsionada por essa obra, é possível refletir a respeito de conceitos importantes de Tillich, como a dinâmica entre o protestantismo e catolicismo que vai muito além do âmbito denominacional, mas que possui significado abrangente à teologia. Querendo ou não, o filme faz o público refletir teologia e o artigo quer explicitar isso analisando o filme, os conceitos de Tillich e por final as suas contribuições contemporâneas. Palavras-chave: Protestantismo. Catolicismo. Teologia da cultura. Paul Tillich.
\end{abstract}

The Two Popes: a reflection on the Protestant principle and the Catholic substance from the theology of culture

\begin{abstract}
The article analyzes the cinematographic work Two Popes from Paul Tillich's theology of culture and his concepts of Protestant principle and Catholic substance. The film presents the viewer with a reflection, from the difference between the two characters, of two destinies and two distinct ecclesiological and theological models. More than the condition
\end{abstract}

* Doutorando em Teologia pelas Faculdades EST, São Leopoldo, RS, Brasil. Bolsista CNPq. E.mail: dumerluterano@gmail.com. Orcid: http://orcid.org/0000-0003-1217-3323 
of contemporary Catholicism, the film brings reflections on theology and Christianity as a whole. Driven by this work, it is possible to reflect again on the important concepts of Tillich, namely the dynamics between Protestantism and Catholicism that go far beyond the denominational scope, but which have a comprehensive meaning to theology. Whether one likes it or not, the film makes the audience reflect on theology and this article is intended to explain this by analyzing the film, Tillich's concepts and, finally, its contemporary contributions.

Key-words: Protestantism. Catholicism. Teology of culture. Paul Tillich.

\section{Considerações iniciais}

Filmes são obras de arte deveras completas. Apresentam uma estória, um roteiro marcado pela atuação de um elenco, além de contar essa estória através de imagens, cenários, silêncios, expressões, tons e músicas. Por tão completa maneira de apresentar sua intenção é comum que filmes revelem reflexões sociológicas, filosóficas e até teológicas. Mais precisamente o filme Dois Papas, inevitavelmente, nos conduz a pensar sobre as relações internas do catolicismo e, para além dele, de todo o cristianismo. Essa reflexão, contudo, depende de ferramentas teológicas que organizem os insights que o filme produz, e, para tanto, não há referência melhor indicada que Paul Tillich, teólogo que se preocupou em examinar a cultura e que compreendeu a dinâmica entre forças, por vezes, opostas e outras complementares da teologia e da religião cristã, isto é, o princípio protestante e a substância católica.

O presente artigo inicia pelo exame da obra Dois Papas como obra de ficção e dos dados históricos no quais que se ancora. A seguir, debruça-se sobre os conceitos fundamentais pelos quais compreende o conteúdo do filme, isto é, os conceitos de princípio protestante e substância católica de Paul Tillich. Num último ponto, através de um itinerário pela obra e conceitos do já referido teólogo, o artigo faz diversas considerações, sempre partindo da provocação do filme, sobre os desafios teológicos contemporâneos. O artigo se presta como um ensaio de teologia da cultura na contemporaneidade, na tradição da teologia tillichiana, que revisa sua obra em vistas à situação presente da teologia e sociedade. 


\section{O filme, os Papas, a Igreja}

O filme Dois Papas estreou no serviço de streaming Netflix em 20 de dezembro de 2019, com roteiro do neozelandês Anthony McCarten e dirigido pelo brasileiro Fernando Meirelles. Protagonizado pelos atores britânicos Jonathan Pryce, no papel do cardeal Jorge Bergoglio, futuro Papa Francisco, e Anthony Hopkins, como Joseph Ratzinger, o Papa Bento XVI, o longa-metragem narra um encontro fictício entre os dois religiosos e diálogos que trazem reflexões filosóficas e teológicas importantes, especialmente para a Igreja Católica na atualidade, mas também, por extensão, para a reflexão teológica do cristianismo como um todo na contemporaneidade. Como uma obra que mistura ficção e realidade, a relação entre os dois papas é "super humanizado", cabendo inclusive a Bento XVI o convencimento de Bergoglio a se tornar papa (OLIVEIRA, 2020).

Os destaques técnicos são, sem dúvida, o roteiro e atuação dos dois atores, e sua boa recepção é demonstrada nas indicações de prêmios como o Globo de Ouro e Oscar de 2020. A respeito dos atores ainda é importante destacar:

Os dois atores são muito diferentes. Hopkins é um pianista, metódico e muito meticuloso, e precisava de um roteiro completamente fechado para trabalhar. Já Pryce é como um músico de jazz, não tão interessado nas palavras como na linguagem corporal e no estado mental do personagem (EFE, 2019).

Os dois atores são uma metáfora convincente das personalidades que a obra pretende apresentar dos dois personagens. Leonardo Boff comenta: "O filme é uma bela metáfora da condição humana, de dois modos diferentes de realizar a humanidade, que não se opõem mas se compõem e se completam, uma com a ternura e a outra com o rigor" (BOFF, 2020).

Central para o filme é a discussão entre as personalidades e visões diferentes a respeito do dogma e da vida de fé entre o então papa e o futuro papa, o que é favorecido pelo roteiro, os diálogos e a atuação dos atores. Essa contraposição entre os dois é feita "de forma quase arquetípica", ou seja, duas forças que compõe o espírito do cristianismo. De um lado está Bergoglio, Francisco, "apresentado como um "revo- 
lucionário", humilde, advogado das causas justas, amigos dos pobres e dos oprimidos"; do outro lado está Ratzinger, Bento XVI, "retratado como esquemático, conservador, alijado do mundo, vaidoso, amante do luxo, intelectual" (REDAÇÃO, 2019). De um lado também há um religioso argentino, latino-americano, de outro um religioso alemão, bávaro, europeu. Estão em dois continentes diferentes, duas culturas e duas realidades político-sociais diferentes, em lados distintos de uma fronteira, e é esse encontro, onde os dois lados da fronteira se cruzam, de tensão e intercâmbio que torna a obra tão extraordinária.

Como arte que imita a vida, é preciso atentar aos papas reais. Boff publicou a respeito, especialmente sobre sua experiência com Ratzinger, professor de teologia, antes de tornar-se Bento XVI. O teólogo brasileiro declara ter uma dívida de gratidão com Ratzinger pela apreciação de sua tese de doutorado, A Igreja como Sacramento Fundamental no Mundo secularizado, além de sua ajuda na publicação da tese. Anos depois, como cardeal e presidente da Congregação para a Doutrina da $F e ́$, Ratzinger, conforme Boff, "teve a ingrata missão de me interrogar sobre o livro Igreja: carisma e poder em 1984" e pouco mais adiante: "Devo reconhecer que ele se sentia constrangido". Boff foi julgado nesse tribunal que teve como resultado sua condenação a um "silêncio obsequioso", mas o teólogo brasileiro torna público o que ouviu dizer: "Soube mais tarde, através de um emissário de seu secretário particular que ele, Card. Ratzinger, votou a meu favor mas foi voto vencido". Quanto a Bergoglio, Boff o conheceu em circunstâncias bem diferentes. O ano foi 1972, onde discutiram sobre duas vertentes da teologia da libertação, "de tipo argentino (do povo silenciado e da cultura oprimida) e a brasileira e peruana (sobre a injustiça social e a opressão histórica sobre os pobres e afrodescendentes)" (BOFF, 2020). Embora em lados diferentes, a relação com Bergoglio era muito menos tensa que o debate com Ratzinger.

O filme, buscando humanizar os dois papas, apresenta ainda os lados tanto "luminosos" como "sombrios" dos dois religiosos. Ratzinger, em seu passado, chegou a fazer parte da juventude nazista (OLIVEIRA, 2020). Nos anos de seu pontificado, pesa sobre ele também a "sua leniência com os pedófilos", sua incapacidade de lidar com tais escândalos. Boff comenta: 
O Papa não se deu conta suficientemente de que não tinha a ver apenas com um pecado perdoável pela confissão. Tratava-se de um crime contra inocentes que a justiça comum deve investigar e punir. Não se pensou nas vítimas, apenas na salvaguarda da imagem da instituição-Igreja (BOFF, 2020).

Além disso, há que se considerar que Bento XVI é um teólogo conservador, o que já vinha na esteira de João Paulo II, e entrincheirou a Igreja contra a modernidade, relativizando as decisões conciliares do Vaticano II, da década de sessenta, e empreendendo um retorno espiritual à disciplina dos concílios de Trento, da Contra-Reforma, e do Vaticano I, do século XIX (BOFF, 2020). O então cardeal com o papa polonês foram responsáveis pela redação de documentos reacionários como Evangelium vitae e Veritatis splendor (OLIVEIRA, 2020). A despeito da consideração que tenha dado a Boff, conforme o mesmo relata, Ratzinger atuou no julgamento de outros 110 teólogos e teólogas, como Ivone Gebara. Os anos de João Paulo II e Bento XVI podem ser chamados de "um inverno eclesial severo". Boff reflete a respeito desses anos:

Toda uma geração de padres foi formada nesse estilo doutrinário e com os olhos voltados ao passado, usando os símbolos do poder clerical. Igualmente, toda uma plêiade de bispos foram sagrados, mais autoridades eclesiásticas ortodoxas que pastores no meio de seu povo (BOFF, 2020).

Mesmo tendo abdicado do papado, Bento XVI voltou recentemente a atuar no destino do catolicismo, juntamente com o cardeal Robert Sarah, posicionando-se contra a ordenação de homens casados ao sacerdócio, tema que o papa Francisco tem se ocupado (VERDÚ, 2020). Ratzinger, assim, representa um catolicismo conservador, até reacionário a respeito da modernidade, fortemente calcado na moral, na ortodoxia e no rito. Bergoglio, por sua vez, traz consigo outro modelo para a Igreja, uma possível primavera após o inverno dos pontificados anteriores.

Boff chama esse modelo de "um hospital de campanha", em vez de uma instituição da moral, e "Igreja em saída", isto é, em saída "para as periferias humanas e existenciais". Isso não significa que ela desconsidere o dogma, mas "que prefere colocar-se vivamente diante do Jesus histórico, opta pelo encontro direto com as pessoas e a pastoral 
da ternura". Esse modelo é o que se centra na misericórdia de Deus, no amor, solidariedade e perdão, em vez do seu julgamento (BOFF, 2020). A Bergoglio, contudo, pesa seu passado durante a ditadura militar argentina, caso explorado pelo filme, em que retirou a proteção de dois padres jesuítas, Pe. Jalics e Pe. Yorio. Com o primeiro, Bergoglio reconciliou-se, mas o segundo, falecido há alguns anos, afastou-se do futuro papa. Ao mesmo tempo, Bergoglio também ofereceu assistência a perseguidos pelo regime, escondendo vários no Seminário Maior de San Miguel (BOFF, 2020). O fato do filme explorar esse passado de Francisco tem o objetivo de humanizar tanto o papa argentino, ao mostrar seu passado, como humanizar o papa alemão, à medida em que demonstra que não fora o único a ter cometido erros.

No filme, se Bento XVI faz Francisco, é Bergoglio que procura a humanidade recolhida de Ratzinger através da comensalidade, da dança, do futebol, não da doutrina. Isto é, a humanidade de Bergoglio faz a humanidade de Ratzinger no filme. Boff conclui:

Vale ver o filme, pois nos faz pensar e nos oferece lições de mútua escuta, de verdades ditas sem rebuços e de uma amizade que vai crescendo na medida em que a relação se descontrai de encontro a encontro. $O$ perdão que um dá ao outro e o abraço final, longo e carinhoso, engrandece o humano e o espiritual presentes em cada um de nós (BOFF, 2020).

O filme certamente é uma exímia obra de arte, prende a atenção no desenrolar da relação entre os dois personagens, ao mesmo tempo em que leva o pensamento além, a refletir sobre os modelos de igreja, teologia, espiritualidade e humanidade. Como uma obra de ficção, permite-se poder criar sua própria narrativa, mas baseando-se em personagens e fatos reais, precisa fazer jus à história que pretende contar. Podemos questionar a equivalência entre os passados de Ratzinger e Bergoglio. Mas mais interessa é o que de teologia o filme revela, e nesse ponto, ele revela uma teologia centrada no conteúdo da doutrina manifestada em formas litúrgicas, dogmáticas e de governo. A outra teologia centra-se igualmente em um conteúdo, mas este não se dá em formas fixas, mas dinâmicas da ação para além das fronteiras da igreja. Queremos a partir de agora investigar esses dois modelos a partir de um binômio conceitual: o princípio protestante e a substância católica. 

e a substância católica a partir da teologia da cultura

\section{O Princípio Protestante e a Substância Católica}

O título dessa seção é uma importante fórmula de um dos teólogos mais relevantes do século XX, o teólogo luterano teuto-estadunidense Paul Tillich. Embora fosse um teólogo protestante, e que manifeste essa tradição teológica com clareza em sua obra, nunca esteve encerrado nos limites confessionais, sempre se posicionando como um teólogo da fronteira, o que lhe permitia um diálogo com a cultura, com a tradição filosófica do ocidente e a tradição cristã como um todo como poucos foram capazes de realizar. A investigação aqui é por ferramentas conceituais que ajudem a entender a dinâmica interna do cristianismo e, nessa investigação, Tillich pode nos ajudar. O cristianismo, segundo Mueller, "herda do judaísmo uma religião com fortes tensões entre o sacerdócio e o profetismo". Essas duas forças, o espírito profético e espírito sacerdotal, estão sempre relacionados em diálogo e tensão, no carisma e no poder, no protestantismo e no catolicismo (MUELLER, 2006, p. 16).

$\mathrm{Na}$ fórmula, Tillich diferencia entre um caráter protestante e um caráter católico no interior do cristianismo. Por exemplo, seria próprio do princípio protestante, a Palavra, e próprio da substância católica, o Sacramento (MUELLER, 2006, p. 7). Por substância se entende a unidade, a preservação, enquanto o princípio é a "consciência norteadora" dessa preservação. Não seria correto entender que só há substância católica no catolicismo, e que esse só fosse composto dela, nem que há princípio protestante apenas no protestantismo, e que esse fosse necessariamente sempre protestante. A substância do protestantismo é a substância católica, pois ela é a substância do cristianismo e o princípio protestante está presente também em várias realizações no catolicismo, isto é, o princípio protestante é a consciência norteadora de todo o cristianismo (MUELLER, 2006, p. 8). De novo, o princípio protestante não possui substância própria, a sua substância é a substância católica (MUELLER, 2006, p. 10). Com esses dois conceitos não se fala, portanto, da relação entre as igrejas protestantes e a igreja católica, mas de uma dinâmica do cristianismo, de duas forças que convivem, nem sempre harmoniosamente, na história da religião cristã.

Para ficar mais claro, Tillich identifica duas maneiras religiosas, a religião de tipo sacerdotal-sacramental, da qual a substância católica 
é correlata, e de tipo profético-teocrática, de onde vem o princípio protestante (MUELLER, 2006, p. 8). O cristianismo é a convivência desses dois tipos, dessas duas ênfases, dessas duas forças religiosas, e ambas são importantes e necessárias. O sacerdócio e o sacramento têm a função de conservar o conteúdo da revelação e para isso se constitui em formas. Há sempre o risco de se confundir os meios de conservação com o próprio conteúdo que eles carregam. Quando isso ocorre, Tillich chama de "demônico", ou seja, a confusão entre forma e conteúdo, entre o relativo e o absoluto, entre o finito e o infinito, o condicional e o incondicional. Onde ocorre essa confusão, essa elevação, levanta-se a profecia, o princípio protestante (MUELLER, 2006, p. 9). Compreendido isso, constata-se que o princípio protestante é, por sua natureza, um princípio negativo, isto é, um protesto contra as formas, aquelas que possam sufocar o conteúdo. Mas não se resume a isso, o princípio protestante também tem um caráter positivo, ou seja, formativo, que cria formas, o que Tillich chama de Gestalt da graça (MUELLER, 2006, p. 10), termo que significa "união do protesto com a criação" (TILLICH, 1992, p. 224). Essa é "a estrutura sagrada ou divina da realidade" (MUELLER, 2006, p. 11) que se contrasta com a forma finita elevada do "demônico".

Em uma obra que trata da eclesiologia protestante, o teólogo luterano brasileiro Vítor Westhelle diferencia entre dois paradigmas eclesiológicos, o econômico, cujo símbolo que utiliza é a casa, e o político, cujo símbolo é a rua (WESTHELLE, 2017, p. 109-110). Na primeira, a identidade é dada, conferida por pertencimento, na segunda é construída nas relações, negociada. Essas duas eclesiologias podem cair em um tipo de cativeiro, cada uma. À eclesiologia da casa, Westhelle relaciona o cativeiro da idolatria. Segundo o teólogo: “O ídolo é a imagem visível que prende o olhar e torna-o incapaz de observar além do quadro da representação" (WESTHELLE, 2017, p. 117). Ídolo aqui pode assumir muitas formas, como um sistema teológico petrificado, uma estrutura de poder incontestável, etc. Como cativeiro da casa, não permite que nenhum ar de fora penetre em seu domínio. Escraviza dentro de si. O ídolo é o eu projetado a caráter absoluto, e o cativeiro idolátrico tenta escravizar o espaço além da casa para dentro dela. 
O outro tipo de cativeiro, que assola a eclesiologia da rua, é do demônio. Esse "aparece através de um ato de invasão, através da possessão. Ao invés da positividade auto-assegurada do ídolo, o demônio nega"; mais adiante: "Enquanto o ídolo cativa o olhar que se torna fixo sobre o eu projetado e idealizado da pessoa, o demônio é a angústia de um sujeito que não pode encontrar o seu próprio eu" (WESTHELLE, 2017, p. 121). O demônio aliena, dissolve o sujeito na rua, sem identidade, cria desordem. Conforme Westhelle: 'Em nome de ser 'relevante', o demônio, como carência de confiança em Deus, ajusta a igreja aos modos do mundo" (WESTHELLE, 2017, p. 125). É um perigo sempre constante, por exemplo, do protestantismo, de confundir seu ethos próprio com o ethos da burguesia ou capitalismo. Para o teólogo, o protesto profético atinge o ídolo, pela denúncia, pela revelação de seu caráter idolátrico. Mas o enfrentamento do poder demônio é pela comunhão (WESTHELLE, 2017, p. 127). Para Tillich, é a graça que tem o poder de vencer o demônico (TILLICH, 1963, p. 54). Há algumas diferenças entre a compreensão de Westhelle e Tillich do poder demônico ou demoníaco, mas concordam no seu poder fragmentador.

É da graça que o protesto do princípio protestante retira seu poder de ser, é a partir dela que esse se orienta. Conforme Tillich: "o protesto só pode existir em relação com certa 'Gestalt' à qual pertence" (TILLICH, 1992, p. 223). O mero protesto sem a Gestalt pode se tornar ortodoxia, o que é um risco permanente do protestantismo (TILLICH, 1992, p. 225). Por outro lado, falar em uma Gestalt, em uma forma da graça, parece colocar em risco justamente o protesto da Reforma contra o condicionamento da graça na hierarquia católica do século XVI (TILLICH, 1992, p. 226). Assim, falar em forma ameaçaria o caráter incondicional e transcendente da graça, porém, essa, ainda que vinda de fora, é acolhida (e nisso reside seu poder) "pela fé, pela Igreja e pelo indivíduo" (TILLICH, 1992, p. 227); a fé é humana e o ser humano é forma. Graça, assim preenche, cria formas e transforma.

Aqui, porém, é preciso diferenciar entre a visão católica e protestante de Gestalt. Na compreensão católica, "a forma finita transmuda-se na forma divina", "a relatividade histórica da Igreja é santificada por seu caráter divino", "e o elemento material do sacramento acaba sendo preenchido pela graça” (TILLICH, 1992, p. 228). Diferente é a visão 
protestante, nessa "a graça aparece por meio de uma Gestalt viva que permanece sendo o que sempre fôra", não ocorre uma transmudação do caráter finito da forma: "As formas da graça são sempre finitas", mas ainda assim "levando-nos para além delas" (TILLICH, 1992, p. 228229). De novo, onde ocorre a confusão da forma finita com o conteúdo incondicional da graça, ali ocorre uma hybris demoníaca, e é somente contra essa hybris que o protesto profético se direciona, não contra que haja formas. A graça, na verdade, torna a forma transparente à transcendência (TILLICH, 1992, p. 229). Essa transparência da realidade à graça é o que Tillich chama (e onde se firma sua teologia) de teonomia (TILLICH, 1992, p. 106). Na teologia de Tillich, a teonomia torna impossível o individualismo, seja ele religioso, emocional ou econômico (TILLICH, 1992, p. 74). Teonomia é comunidade e exige comunidade.

É orientado por ela que o protestantismo pode realizar seu protesto contra as formas e aqui o princípio protestante pode protestar contra a própria igreja (MUELLER, 2006, p. 12). A igreja protestante, para Tillich, é Gestalt da graça, pois une protesto e forma. Mas ser Gestalt da graça significa não confundir seu caráter de portadora com a própria graça, e isso significa que o princípio protestante, seu protesto, se dirige também contra o próprio protestantismo (TILLICH, 1992, p. 229). O princípio protestante:

É a força crítica e dinâmica presente em todos os feitos protestantes, sem se identificar com nenhum deles (...). Trata-se de um poder vivo, dinâmico e atuante (...). Contém o protesto divino e humana contra qualquer reivindicação absoluta feita por realidades relativas, incluindo mesmo qualquer Igreja protestante. O princípio protestante é o juiz de qualquer realidade religiosa e cultural, incluindo a religião e a cultura que se chamem "protestantes" (TILLICH, 1992, p. 183).

Aqui vale trazer outro teólogo brasileiro, Rubem Alves. Em um texto de 1970 pergunta-se se há futuro para o protestantismo na América Latina. Para o teólogo brasileiro, a questão move-se na antinomia entre comunidade e estrutura. Sua crítica é que o protestantismo na América Latina não chegou a criar uma era protestante, pois desde cedo envelheceu, perdeu seu poder criativo, seu poder de criar comunidade para se tornar estrutura, rigidez doutrinária e moral (ALVES, 1982, p. 131-132). 
Sua grande contribuição ao debate a respeito do princípio protestante é explicitar que esse princípio é a comunidade e não o individualismo, que se tornou marca do mesmo (ALVES, 1982, p. 133). Para Alves, também, há uma distinção entre uma sociologia medieval, fundamentada na ideia de ordem e uma sociologia da Reforma, que redescobre o que já estava nos profetas, a história (ALVES, 1982, p. 134), que liberta a eclesiologia protestante do aprisionamento dogmático e mesmo moral. Em vez de uma comunidade sacerdotal e, portanto, alicerçada em uma estrutura de poder, ela é uma comunidade profética, que extravasa as fronteiras em direção do futuro e crítica de todo poder (ALVES, 1982, p. 145). Ou como conclui Westhelle: "A 'natureza' da igreja é escatológica” (WESTHELLE, 2017, p. 41), isto é, histórica, profética.

De volta a Tillich, ele compreende que o protesto inerente do protestantismo não é meramente dirigido contra a igreja, a teologia, mas contra qualquer reivindicação absoluta. É protesto contra o autoritarismo, seja de uma teologia, uma igreja, um Estado ou uma forma econômica. É protesto também contra uma autonomia autocentrada, autodeterminada que carrega consigo a possibilidade de autocontradição e autodestruição (TILLICH, 1992, p. 185). Tillich destaca melhor o significado: "Uma das mais importantes funções do princípio protestante consiste em revelar essas ideologias concretas, da mesma maneira como faziam os profetas quando atacavam a ordem religiosa e social de sua época" (TILLICH, 1992, p. 189). Em um escrito de 1931 chamado $O$ princípio protestante e a situação do proletariado, Tillich coloca esse protesto em relação ao protesto vindo da classe proletária contra os sistemas econômicos, políticos, sociais que a explorava.

O princípio protestante não é uma propriedade do protestantismo, longe disso, mas é todo o protesto, advindo da graça, contra a escravidão, morte e violência de sistemas políticos e econômicos. Como espírito profético, manifesta-se em diferentes momentos e contextos. Também a teologia da libertação, que surge tanto no meio da teologia protestante, através de Rubem Alves, como do meio católico, através de Gustavo Gutierrez, são expressões desse espírito profético. Espírito profético não faz apologia de sua instituição, mas profetiza inclusive contra ela, quando essa se afasta do seu conteúdo. 
Não é preciso usar o nome do conceito quando seu significado nos ajuda a entender a dinâmica das forças de tensão do cristianismo. No filme se contrastam um espírito profético, representado por Bergoglio e um espírito sacerdotal, representado por Ratzinger, em diferentes momentos do roteiro. O contraste dessas duas forças, porém, deve ultrapassar a dinâmica interna do filme, ou mesmo para seu significado no momento atual do catolicismo, da diferença de modelos de Francisco de Bento XVI. O significado deve se estender, primeiramente, para a teologia como um todo, também a protestante, e por último, como obra de arte secular, à sociedade. Isso é tarefa da teologia da cultura.

\section{Os dois Papas através da teologia da cultura}

A teologia da cultura de Tillich surgiu em 1919 em uma palestra com o título Sobre a ideia de uma teologia da cultura onde levanta a questão que a teologia não pode mais procurar impor sua ética para o resto do mundo, mas deve reconhecer "a existência de uma comunidade cultural externa à Igreja" (PINHEIRO apud TILLICH, 2009, p. 15). Dessa forma, toda a vida cultural externa da igreja, como a ciência, arte e vida social são objetos de análise da teologia da cultura (TILLICH, 1967, p. 16). Mas isso não significa que dentro do sistema teológico tillichiano o dogma não era importante. Para o teólogo: "O conceito de dogma situa-se na fronteira entre a igreja e o mundo secular" (TILLICH, 2015 , p. 20). O dogma é uma tradução do elemento da revelação, o incondicional, dentro de um contexto social, cultural, intelectual de uma época. A teologia da cultura não dispensa o dogma, mas compreende que o mesmo é um esforço de correlação, e não se alheia dessa tarefa inerente do fazer teológico.

Um princípio fundamental da teologia da cultura é seu método, isto é, o método de correlação, que procurava correlacionar as respostas teológicas às perguntas existenciais presentes na cultura. Mais que um simples exercício de perguntas e respostas, o método tem um significado profundo no sistema teológico de Tillich e dentro do seu grandioso projeto de teologia da cultura. É porque a resposta teológica só tem (e terá) sentido porque está correlacionada a uma pergunta existencial humana. Diz o teólogo em sua Teologia Sistemática: 
Só as pessoas que experimentaram o choque da transitoriedade, a angústia na qual se tornam conscientes de sua finitude, a ameaça do não-ser, podem entender o que significa a palavra Deus. Só as que experimentaram as ambiguidades trágicas de nossa existência podem compreender o que significa o símbolo do Reino de Deus (TILLICH, 2005, p. 76).

Esse método é possível porque Tillich entende que em toda a situação humana está presente, sempre, uma preocupação religiosa. Para ele:

A preocupação religiosa é última. Ela despoja todas as outras preocupações de uma significação última. Ela as transforma em preliminares. A preocupação última é incondicional, independente de qualquer condição de caráter, desejo e circunstância. A preocupação incondicional é total: nenhuma parte de nós mesmos ou de nosso mundo está excluída dela. Não há "lugar" onde nos possamos esconder dela. A preocupação total é infinita: nenhum momento de relaxamento ou descanso é possível em face da preocupação religiosa que é última, incondicional, total e infinita (TILLICH, 2005, p. 29).

Compreende-se, então, que o método teológico próprio da teologia tillichiana, da teologia da cultura, é carregada de uma tensão, o encontro com o incondicional não é de forma alguma uma mera curiosidade acadêmica, mas é escatológico, é assunto de vida e morte. É claro que a teologia decorrente desse método pode tornar-se uma teologia intransigente. Aqui, coloca-se novamente o princípio protestante, levando sempre de volta ao sim e não de Deus ao mundo, o que inclui a teologia.

A análise de uma obra de arte, como o filme Dois Papas o é, através da teologia da cultura passa pelos conceitos de substância católica e princípio protestante. A análise passa também pela ideia de símbolo. O símbolo, para Tillich, participa do poder e do sentido daquilo que comunica, para o qual aponta (TILLICH, 2009, p. 100-101). Na verdade, o símbolo comunica muito mais que a linguagem, ele abre níveis da realidade, gera abertura, abre ao toque do incondicional, é transparente. A religião é composta de símbolos: os dogmas, a liturgia, etc. O dogma não é apenas uma opinião, uma especulação de uma ideia religiosa, mas participa do poder daquilo que comunica. A liturgia não é apenas performance de um estado religioso, mas participa do poder daquilo que comunica. 
O símbolo participa do incondicional que o preenche, é como uma Gestalt da graça, mas o símbolo não é o incondicional. Quem o lembra disso é o princípio protestante. Faz parte do núcleo do pensamento protestante "a distância infinita entre Deus e ser humano", também "a finitude humana, a morte, mas acima de tudo, a separação de nosso ser verdadeiro e a escravidão às forças demoníacas - forças de autodestruição" (TILLICH, 2009, p. 113). O princípio protestante também serve para interpretar uma obra de arte. Tillich mesmo diz que o quadro Guernica de Pablo Picasso é um quadro protestante. A isso o teólogo explica:

Picasso põe diante de nós, com tremenda força, a questão do ser humano num mundo de culpa, ansiedade e desespero. Mas não é o tema da tela - a destruição total de uma pequena cidade por aviões fascistas - que dá ao quadro tal força expressiva; é, antes, seu estilo (...). Esse estilo, como nenhum outro na história do protestantismo, expressa a situação humana como o cristianismo a percebe (TILLICH, 2009, p. 114).

O princípio protestante na arte significa a expressão da cruz, que expressa a situação limítrofe do ser humano, sua culpa, ansiedade, desespero, sofrimento, morte, mas não só, que expressa também a aceitação do ser humano, a acolhida desse (TILLICH, 2009, p. 120). A teologia da cruz é uma marca central da teologia protestante. $\mathrm{Na}$ verdade, ela "não é uma teologia entre outras nem uma doutrina, mas uma maneira de fazer teologia", isto é, fazer teologia na cruz, com o(s) crucificado(s) (WESTHELLE, 2008, p. 119). A cruz, nessa forma de se fazer teologia, "torna-se um lócus epistemológico, o lugar privilegiado da auto-revelação do próprio Deus" (WESTHELLE, 2008, p. 119-120).

O teólogo católico, e jesuíta, radicado em El Salvador, elabora a ideia de "honradez com o real", que não significa outra coisa que o postulado da teologia da cruz. Encobrir a realidade, isto é, a realidade das vítimas, "é um verdadeiro escândalo" (SOBRINO, 2007, p. 65). E é mesmo em diálogo a outro teólogo luterano, Rudolf Otto, que traduz o que significa santidade primordial, ou seja, aquilo que é incondicional, aquilo que toca a totalidade do ser humano, a saber, a "primariedade e ultimicidade da vida" (SOBRINO, 2007, p. 112). É esse o único incondicional que vence a prisão de uma autonomia egocentrada, é um 
incondicional que não se apresenta como lei, força violenta, heteronomia. Esse incondicional deixa a imanência transparente, é "o que tem força para atrair, para con-vocar, para nos tirar de nós mesmos porque ouvimos um chamado sobre o qual não podemos dispor" (SOBRINO, 2007, p. 129). Esse incondicional forma comunidade, rompe as expectativas cronológicas, porque é kairós.

Essa teologia, levantada por Lutero em 1518, diferencia-se de uma teologia da glória. O caráter da teologia da cruz é "dizer as coisas como elas são", não esquivando-se da finitude e impotência mostrada na cruz e no(s) crucificado(s), entende a revelação dentro dos limites da situação humana. Para Tillich:

O elemento protestante no protestantismo é a proclamação radical da situação-limite da vida humana, e o protesto contra todas as tentativas, mediante expedientes religiosos, de evadi-la, mesmo quando por meio da riqueza, da profundidade e da amplitude da piedade mística e sacramental (TILLICH, 1992, p. 212).

O protesto, porém, não pode ser dado de modo que a igreja esqueça seu sentido, sua substância. Não pode apenas ser negação, mas precisa ser afirmação criadora e criativa. A mensagem protestante, para Tillich, é, sim, em primeiro lugar a proclamação da situação-limite do ser humano (TILLICH, 1992, p. 218), pois é essa proclamação que não permite a igreja a iludir-se consigo mesma. Mas não é apenas mensagem negativa, mas também afirmativa, um Sim de Deus, um Sim incondicional, Sim vivificante, Sim de graça. Por último, a mensagem protestante precisa se tornar realidade concreta, o que Tillich chama de "novo ser". O "novo ser" é Jesus, é onde o divino encarna na realidade humana, é "teonomia". Esta não é nem uma submissão da cultura à religião nem a dissolução da religião na cultura (TILLICH, 1992, p. 220), mas cultura carregada de seu sentido último, completamente aberta e, portanto, não fechada à situação-limite do ser humano.

A teologia da cruz não é um anúncio mórbido, mas, conforme elabora Vítor Westhelle, "prática da ressurreição". Segundo o mesmo: "Essa é a tarefa dos seguidores e das seguidoras de Cristo: não permitir que a história termine em calamidade, não permitir que o passado seja fechado, contra toda evidência, contra toda a esperança" (WESTHELLE, 
2008, p. 129). A prática da ressurreição é possível na teologia da cruz, pois o serviço ao corpo do crucificado, em referências às mulheres que procuraram o corpo de Jesus após o sábado da paixão, o serviço ao corpo que nada mais tem a oferecer, é serviço de amor desinteressado, gratuito. E apenas o escândalo da cruz pode mover um amor tão fora do egoísmo (WESTHELLE, 2008, p. 132). É nisso que se manifesta teonomia, comunidade, autonomia tocada pelo incondicional. A solidariedade desencadeada pela transparência do incondicional na realidade é sempre prática da ressurreição, porque é sempre vida, ainda que seja vida em meio à morte, ali "impõe-se a força da vida" que vence a força da morte (SOBRINO, 2007, p. 34).

$\mathrm{O}$ incondicional que o princípio protestante lembra não é e não pode ser uma questão doutrinária a respeito da correta interpretação dos dogmas, não é ortodoxia, mas é a lembrança do que o dogma de fato comunica, a saber, o incondicional que é vida contra a morte. $\mathrm{O}$ incondicional que a substância católica preserva não é e não pode ser uma questão de manutenção de uma forma eclesiástica, doutrinária, litúrgica, mas preserva a comunidade preenchida e determinada pelo incondicional, pela vida contra a morte. O significado da obra Dois Papas, assim, vai além de lidar com as duas personalidades dos dois personagens. Em xeque ali está uma igreja, uma religião, uma fé preocupada em preservar a si mesma e outra que se coloca ao serviço transformador no mundo.

No livro Igreja: Carisma e Poder, Boff aponta para isso ao destacar logo de início: “A Igreja não pode ser entendida nela e por ela mesma, pois está a serviço de realidades que a transcendem, o Reino e o mundo" (BOFF, 2005, p. 25). Igreja, nessa definição, vem apenas após o Reino, como categoria escatológica, revelatória, e o mundo, o lugar de historicização. Igreja é sinal do Reino no mundo, é sacramental (BOFF, 2005, p. 26). A igreja não subsiste para si, nem o dogma para si, mas sempre em relação ao Reino, pelo qual é determinada, e ao mundo, onde é realidade. Para Boff, ainda, há dois comportamentos na igreja: o de voltar-se para o mundo e o voltar-se para si mesma (BOFF, 2005, p. 113). O Concílio Vaticano II procurou transformar a eclesiologia católica ao tirar a ênfase da hierarquia, o seu voltar-se a si, para a ênfase no povo de Deus, mas essa transformação ainda é um desafio 
no catolicismo, como se revela na relação dos modelos de Bento XVI e Francisco. Em xeque aqui está a crítica à igreja como poder fechado em si (BOFF, 2005, p. 135).

O protesto profético se direciona contra não que se haja instituição, não que se haja doutrina, não que se haja liturgia, isso tudo é importante e necessário. O princípio protestante não se direciona contra a substância católica, de modo algum. O princípio protestante se direciona contra a hybris de uma religiosidade voltada a si, seja na forma de piedade, de doutrina ou de projeto de poder. Portanto, o princípio protestante se volta contra o protestantismo quando esse demonizou-se pela autossuficiência e projeto dominador. Alves já tinha a preocupação com o futuro de um protestantismo fechado em sua doutrina (ALVES, 1982, p. 147-148). A preocupação de Tillich era, ainda na primeira metade do século, se o protestantismo seria capaz de ser uma igreja de massas (TILLICH, 1992, p. 245). A Igreja capaz de ter alguma relevância é uma Igreja sob a cruz, "a Igreja que prega o Crucificado" (TILLICH, 1972, p. 145). Essa Igreja não tem poder nenhum que não o poder da graça.

Por último, ao se falar de projetos de poder, é preciso se perguntar pelo protesto profético do princípio protestante contra instituições, movimentos e lideranças que se apresentam como protestantes, mas na verdade são um projeto de poder. Há anos há um processo de tomada de espaços públicos, como a mídia, a política etc., por igrejas, conforme examina Guilherme Casarões (CASARÕES, 2020). Esse questionamento, contudo, deve ser direcionado aos fundamentos teológicos que inspira tal projeto. A crítica deve ser teológica, a fim de adentrar na superestrutura do projeto, investigar seus pressupostos e postular o protesto negativo (que revela seu caráter idolátrico e demônico) e afirmativo (que tem poder criativo de formas da graça).

\section{Considerações finais}

Nesse artigo, a partir da provocação do filme Dois Papas e dos questionamentos teológicos que carrega, realizamos uma reflexão organizada pelos conceitos do pensamento tillichiano. Não é preciso repetir o que já expomos anteriormente, mas sim postular algumas conclusões e desafios. O princípio protestante representa o protesto contra as formas de dominação cultural, política, econômica e religiosa. No contexto 
atual brasileiro, tanto social como eclesial, é uma atitude protestante perguntar-se constantemente se a religião que afirma ser protestante está realizando esse protesto divino ou se se coloca a serviço da dominação. Isso certamente traz consigo um protesto ao protestantismo brasileiro e sua atuação política das últimas décadas.

Nesse quadro, a sustância católica também relembra o valor de preservar valores e conteúdos de fé, comunhão e vivência. A tendência protestante de colocar-se em cruzada contra o chamado mundo, pela sua tendência negativa de formas deve ser contrabalanceado com uma tendência mais contemplativa e de sentimento de pertencimento universal. Com isso se quer dizer que a tendência do espírito protestante de desencantamento do mundo traz algumas consequências políticas e econômicas, de exploração do meio-ambiente, por exemplo, além do desencantamento do próprio ser humano. A teologia da cultura pretende recuperar a transparência da imanência à transcendência, denunciar o individualismo egocentrado e imaginar (criar e conceder imagens) de comunhão com o próximo, o mundo e com Deus.

Esses dois espíritos da religião cristã conduzem um ao outro à sua plena realização, ao mesmo tempo em que freia suas tendências absolutizantes de si. A substância deve estar aberta ao protesto e o protesto não pode perder de vista o conteúdo no qual se baseia e na direção do qual trilha seu caminho.

\section{Referências}

ALVES, Rubem. Dogmatismo e tolerância. São Paulo: Paulinas, 1982.

BOFF, Leonardo. Dois Papas: dois modelos de homem, dois modelos de Igreja. Artigo de Leonardo Boff. In: Revista IHU on-line. Instituto Humanitas Unisinos. Jan. de 2020. Disponível em: <http://www.ihu.unisinos.br/78-noticias/595351-dois-papas-dois-modelos-de-homem-dois-modelos-de-igreja-artigo-de-leonardo-boff> Acesso em: 21.09.20 às 10h.

BOFF, Leonardo. Igreja: Carisma e Poder. Ensaios de eclesiologia militante. Ed. rev. Rio de Janeiro/São Paulo: Record, 2005.

CASARÕES, Guilherme. Religião e Poder: a Ascensão de um Projeto de "Nação Evangélica" no Brasil? In: Interesse Nacional. Disponível em: <http:// interessenacional.com.br/2020/04/03/religiao-e-poder-a-ascensao-de-um-projeto-de-nacao-evangelica-no-brasil/> Acesso em 27.09.20 às 20h. 
EFE. "Dois Papas": Meirelles usa humor para relato sobre papa Francisco. In: Exame. Dez. de 2019. Disponível em: <https:/exame.com/estilo-de-vida/ dois-papas-meirelles-usa-humor-para-relato-sobre-papa-francisco/> Acesso em: 22.09.20 às $11 \mathrm{~h}$.

MUELLER, Ênio R. "Princípio protestante e substância católica": subsídios para a compreensão de uma importante fórmula de Paul Tillich. p. 5-18. In: Correlatio. v. 5, n. 10, 2006. Disponível em: <https://www.metodista.br/revistas/revistas-ims/index.php/COR/article/view/1709/1698> Acesso em 21.09.20 às $11 \mathrm{~h}$.

OLIVEIRA, Tânia M. S. de. Dois Papas: quando a arte não imita a vida. In: Brasil de Fato. Jan. de 2020. Disponível em: <https://www.brasildefato. com.br/2020/01/15/dois-papas-quando-a-arte-nao-imita-a-vida > Acesso em: 22.09 .20 às $10 \mathrm{~h}$.

REDAÇÂO. 'Dois Papas': o que é realidade e ficção no novo filme da Netflix. In: BBC News. Dez. de 2019. Disponível em: <https://www.bbc.com/ portuguese/geral-50924694> Acesso em 23.09.20 às 10h.

SOBRINO, Jon. Onde está Deus?: terremoto, terrorismo, barbárie e utopia. São Leopoldo: Sinodal, 2007.

TILLICH, Paul. A coragem de ser. 2. ed. Rio de Janeiro: Paz e Terra, 1972.

TILLICH, Paul. A era protestante. São Bernardo do Campo: Instituto Ecumênico de Pós-Graduação em Ciências da Religião, 1992.

TILLICH, Paul. Das Dämonische: Ein Beitrag zur Sinndeutung der Geschichte. p. 42-71. Gessamelte Werke: Der Widerstreit von Raum und Zeit. Schriften zur Geschichtsphilosophie. Band VI. Stuttgart: Evangelisches Verlagswerk, 1963.

TILLICH, Paul. História do pensamento cristão. 5. ed. São Paulo: ASTE, 2015.

TILLICH, Paul. Teologia da cultura. São Paulo: Fonte Editorial, 2009.

TILLICH, Paul. Teologia Sistemática. 6. ed. rev. São Leopoldo: Sinodal, 2005.

TILLICH, Paul. Über die Idee einer Theologie der Kultur. p. 13-31. Gesammelte Werke: Die religiöse Substanz der Kultur. Schriften zur Theologie der Kultur. Band IX. Stuttgart: Evangelisches Verlag, 1967.

VERDÚ, Daniel. Uma fissura entre os dois papas. In: El País. Jan. De 2020. Disponível em: <https://brasil.elpais.com/sociedade/2020-01-14/uma-fissura-entre-os-dois-papas.html> Acesso em 23.09.20 às 11h.

WESTHELLE, Vítor. O Deus escandaloso: o uso de abuso da cruz. São Leopoldo: Sinodal/EST, 2008.

WESTHELLE, Vítor. O evento igreja: chamado e desafio a uma igreja protestante. São Leopoldo: Sinodal/EST, 2017. 